\title{
PEMBATALAN PERATURAN DAERAH OLEH MENTERI DALAM NEGERI DALAM TINJAUAN UNDANG-UNDANG NOMOR 23 TAHUN 2014 JUNCTO UNDANG NOMOR 9 TAHUN 2015 TENTANG PEMERINTAHAN DAERAH
}

\author{
Anas Saba'ni \\ Fakultas Hukum Universitas Wahid Haysim Semarang \\ anas_istana99bintang@yahoo.com
}

\begin{abstract}
Abstrak
Hadirnya otonomi daerah telah membawa dampak pada pembuatan sebagian Peraturan Daerah yang kurang sesuai dengan hierarki peraturan perundangundangan. Hal ini berdampak pada pembatalan Peraturan Daerah. Dalam UU No 23 Tahun 2014 jo Undang-Undang Nomor 9 tahun 2015 tentang Peraturan Perundang-Undangan disebutkan bahwa kewenangan pembatalan Peraturan Daerah ada pada Menteri Dalam Negeri, sementara dalam UUD Negara Republik Indonesia 1945 menyebutkan bahwa kewenangan pengujian terhadap peraturan perundang-undangan di bawah UUD Negara Republik Indonesia 1945 berada pada Mahkamah Agung. Oleh karena itu peneliti melakukan penelitian terkait kewenangan pembatalan perda dalam kerangka hierarki peraturan perundangundangan Indonesia.
\end{abstract}

Kata kunci: pembatalan, peraturan daerah, menteri dalam negeri

\section{A. Pendahuluan}

\section{Latar Belakang}

Negara Indonesia menganut prinsip "Negara hukum yang dinamis" atau Welfare State sebagaimana tercantum dalam Pasal 1 ayat (3) Undang-Undang Dasar Negara Republik Indonesia Tahun 1945 yang merumuskan "Negara Indonesia adalah Negara Hukum". Negara hukum merupakan dasar suatu negara dalam melaksanakan tindakan yang menempatkan asas legalitas sebagai dasar tindakan dari suatu negara. ${ }^{1}$

Konsep negara hukum ini sendiri erat kaitannya dengan asas legalitas yang memberikan dasar serta kepastian akan suatu tindakan yang dilakukan oleh

\footnotetext{
${ }^{1}$ A. Mukthie Fadjar, Tipe Negara Hukum, Malang: Bayumedia Publishing, 2005, hlm.59.
} 
pemerintah serta memudahkan masyarakat untuk mengontrol tindakan pemerintah tersebut apakah telah sesuai dengan Peraturan Perundang-undangan.

Berdasarkan Pasal 7 Ayat (1) Undang-Undang Negara Republik Indonesia Nomor 12 Tahun 2011 tentang Pembentukan Peraturan Perundang-undangan, jenis dan hierarki Peraturan Perundang-Undangan terdiri atas:

a. Undang-Undang Dasar Negara Republik Indonesia Tahun 1945;

b. Ketetapan Majelis Permusyawaratan Rakyat;

c. Undang-Undang/Peraturan Pemerintah Pengganti Undang-Undang;

d. Peraturan Pemerintah;

e. Peraturan Presiden;

f. Peraturan Daerah Provinsi; dan

g. Peraturan Daerah Kabupaten/Kota.

Hierarki Peraturan Perundang-Undangan tersebut menyebutkan kedudukan Peraturan Daerah (Perda) sebagai bagian dari suatu peraturan perundangan yang diakui dalam hukum Indonesia. Diletakannya Perda sebagai bagian dari hierarki Peraturan Perundang-Undangan menunjukkan bahwa Perda tersebut hendaknya tidak bertentangan dengan Peraturan Perundang-Undangan yang lebih tinggi sehingga apabila terjadi pertentangan maka sudah sewajarnya Perda tersebut dapat dibatalkan dan dinyatakan tidak berlaku.

Banyaknya pengujian terhadap peraturan daerah yang dilakukan oleh pemerintah tidak sepenuhnya diterima baik oleh daerah-daerah. Pada kenyataannya banyak daerah yang merasa keberatan jika peraturan daerah yang telah dibuat dengan susah payah, membutuhkan biaya yang banyak dan waktu yang lama dan melibatkan wakil rakyat pada Dewan Perwakilan Rakyat Daerah pada akhirnya dibatalkan oleh Menteri Dalam Negeri, sehingga mereka berpendapat oleh karena peraturan daerah yang sudah disahkan dan dibuat dengan cara yang benar untuk kepentingan rakyat, tidak begitu saja dapat dibatalkan dan seandainya dibatalkan pun harus melalui prosedur hukum yang sesuai peraturan perundang-undangan. 
Prosedur yang dimaksud adalah melalui Mahkamah Agung karena Mahkamah Agung dapat melakukan judicial review terhadap peraturan daerah yang dinilai bermasalah untuk membuktikan apakah peraturan daerah-peraturan daerah itu bertentangan dengan Peraturan Perundang-Undangan yang lebih tinggi derajatnya atau tidak. Pasal 24 A Ayat (1) UUD 1945 merumuskan: "Mahkamah Agung Berwenang mengadili pada tinggkat kasasi, menguji Peraturan PerundangUndangan dibawah Undang-undang di bawah Undang-undang terhadap Undangundang, dan mempunyai wewengang lainnya yang diberikan oleh Undangundang".

Berdasarkan Pasal 1 ayat (2) UUD 1945 merumuskan, "Kedaulatan berada di tangan rakyat dan dilaksanakan menurut Undang-Undang Dasar". Berdasarkan ketentuan tersebut dapat diartikan, bahwa pemilik kedaulatan dalam negara Indonesia ialah rakyat. Pelaksanaan kedaulatan ditentukan menurut Undang-Undang Dasar. Pelaksana kedaulatan negara Indonesia menurut UUD 1945 adalah rakyat dan lembaga-lembaga negara yang berfungsi menjalankan tugas-tugas kenegaraan sebagai representasi kedaulatan rakyat. Berdasarkan hal tersebut maka ketentuan Pasal 24 A Ayat (1) UUD Negara Republik Indonesia 1945 tersebut memiliki kedudukan lebih tinggi sebagaimana dalam urutan Hierarki Pembentukan Peraturan Perundang-Undangan dan juga sebagai wujud kedaulatan rakyat.

Kewenangan yang diberikan kepada daerah khususnya dalam hal membuat Peraturan Perundang-Undangan dalam hal ini Perda, selama ini terasa ditanggapi secara berlebihan. Pemerintah daerah berlomba-lomba membuat peraturan daerah sesuai keinginan daerah tanpa memperhatikan ketentuan aturan yang lebih tinggi maupun kepentingan masyarakat umum, sehingga ratusan peraturan daerah yang masuk ke pemerintah pusat dinyatakan bermasalah, bahkan banyak peraturan daerah yang dibuat hanya untuk kepentingan memasukkan pendapatan asli daerah semata, sehingga memberatkan masyarakat. Selain itu banyak perda yang tidak dapat secara optimal dapat diimplementasikan dan ada banyak perda yang 
diprotes oleh warganya sendiri karena tidak sesuai dengan aspirasi masyarakat bahkan sampai pada tingkat judicial review ke Mahkamah Agung.

Pandangan ideal tentang Perda tersebut seolah-olah menjadi kontradiksi antara Undang-Undang Dasar dengan Undang-Undang Pemerintahan Daerah yang memberikan kewenangan kepada Menteri Dalam Negeri untuk membatalkan Perda. Pasal 251 ayat (1) UU No 23 Tahun 2014 Tentang Pemerintah Daerah merumuskan bahwa "Perda Provinsi dan peraturan gubernur yang bertentangan dengan ketentuan Peraturan Perundang-Undangan yang lebih tinggi, kepentingan umum, dan/atau kesusilaan dibatalkan oleh Menteri”. Faktanya Menteri Dalam Negeri telah membatalkan 139 Peraturan Daerah dari tahun 2014 sampai dengan tahun 2015.2

Berdasarkan uraian tersebut diatas, penulis menilai adanya aturan yang tidak sinkron yang mengatur tentang kewenangan pembatalan peraturan daerah. Pertimbangan tersebut dibutuhkan suatu kajian yuridis normatif dalam penelitian tesis ini untuk mengkaji dan menganalisis mengenai pengujian pembatalan peraturan daerah dalam praktik ketatanegaraan di Indonesia.

\section{B. Metode Penelitian}

Metode pendekatan yang digunakan dalam penelitian ini adalah pendekatan yuridis empiris. Penelitian yuridis dilakukan dengan cara meneliti bahan-bahan pustaka yang merupakan data sekunder dan juga disebut penelitian kepustakaan. Sedangkan penelitian empiris dilakukan dengan cara meneliti di lapangan yang merupakan data primer $^{3}$. Sedangkan spesifikasi yang dipergunakan dalam penelitian ini adalah deskriptif analitis dengan menggunakan jenis data primer dan data sekunder. Metode pengumpulan data dilakukan melalui dua kegiatan penelaahan data yaitu penelitian kepustakaan dan dokumentasi yang kemudian dianalisis secara kualitatif sosiologis dengan didasarkan

2 Sejak November 2014 hingga Mei 2015 Mendagri Batalkan 139 Perda, http://nasional.kompas.com/_, diakses pada 3 Januari 2016.

3 Ronny Hanitijo Soemitro, Metodologi Penelitian Hukum dan Yurimetri, Jakarta: GhaliaIndonesia, 1990, hlm. 9. 
pada kedalaman data yang akan dihimpun secara menyeluruh, sistematis, kritis dan konstruktif untuk dapat memberikan jawaban terhadap semua permasalahan dalam penelitian ini.

Penelitian tentang pembatalan perda ini menggunakan beberapa teori untuk mempertajam penelitian, diantaranya; Menurut Montesquieu untuk tegaknya negara demokrasi perlu diadakan pemisahan kekuasaan negara ke dalam 3 organ, yaitu:a) Kekuasaan Legislatif (membuat undang-undang).b) Kekuasaan Eksekutif (melaksanakan undang-undang).c) Kekuasaaan yudikatif (mengadili bila terjadi pelanggaran atas undang-undang) 4 .

Gustav Radbruch mengemukakan bahwa terdapat tiga nilai dasar hukum, yaitu keadilan, kemanfaatan, dan kepastian hukum5. Nilai Keadilan menunjuk pada kesamaan hak di depan hukum, nilai kemanfaatan menunjuk pada tujuan keadilan yaitu memajukan kebaikan dalam hidup manusia, dan nilai kepastian menunjuk bahwa hukum yang berisi keadilan dan norma yang mencitakan keadilan benar-benar berfungsi sebagai peraturan yang harus ditaati.

\section{Hasil Penelitian dan Analisis}

\section{Kedudukan Hukum Pembatalan Peraturan Daerah oleh Menteri Dalam Negeri}

Sistem pemerintahan merupakan bagian penting dalam eksistensi suatu negara. Sistem pemerintahan dapat diartikan sebagai hubungan antara kekuasaan eksekutif di satu pihak dengan kekuasaan legislatif dilain pihak. Eksekutif dalam konteks di atas dalam arti sempit yaitu menunjuk kepada kepala cabang kekuasaan eksekutif atau the supreme head of the executive departement. Apabila dihubungkan dengan UUD 1945, yang dimaksud dengan kepala cabang kekuasaan eksekutif tersebut adalah Presiden selaku kepala pemerintahan sebagaimana ditegaskan di dalam Pasal 4 ayat (1) UUD 1945 yang menyatakan

\footnotetext{
hlm. 152 .

${ }^{5}$ Satjipto Raharjo, Ilmu Hukum, Bandung: Citra Aditya Bakti, 2000, hlm. 19.
}

${ }^{4}$ Miriam Budiardjo, Dasar-Dasar Ilmu Politik, Jakarta: Gramedia Pustaka Utama, 2005, 
bahwa Presiden Indonesia memegang Kekuasaan pemerintahan menurut UndangUndang Dasar. $^{6}$

Menurut teori Hukum Tata Negara dikenal dua bentuk sistem pemerintahan yaitu sistem pemerintahan parlementer dan sistem pemerintahan presidensiil (presidensial).7 Tetapi dalam praktek ada juga dikenal sistem pemerintahan campuran yang disebut sistem parlementer tidak murni atau presidensiil tidak murni.8

Sistem parlementer merupakan sistem pemerintahan di mana hubungan antara eksekutif dan badan perwakilan (legislatif) sangat erat. Hal ini disebabkan adanya pertanggungjawaban para Menteri terhadap Parlemen. Maka setiap kabinet yang dibentuk harus memperoleh dukungan kepercayaan dengan suara terbanyak dari parlemen.9 Oleh karenanya, kebijakan pemerintah atau kabinet tidak boleh menyimpang dari apa yang dikehendaki oleh parlemen.

Sistem presidensial bermula dari sejarah politik latar belakang kebencian rakyat Amerika terhadap pemerintahan Raja George III, sehingga tidak menghendaki monarki untuk mewujudkan kemerdekaannya dari Inggris dan lebih suka mengikuti jejak Montesquieu dengan pemisahan kekuasaan sehingga tidak ada kemungkinan kekuasaan yang satu akan melebihi kekuasaan yang lainnya sebagaimana ajaran Trias politika.10 Dalam menjalankan tugasnya Presiden dibantu oleh menteri-menteri.

Ketentuan mengenai Menteri diatur pada Bab V tentang Kementerian Negara dalam Pasal 17 Undang-Undang Dasar Negara Republik Indonesia Tahun

\footnotetext{
${ }^{6}$ Rukmana Amanwinata, Sistem Pemerintahan Indonesia, Jurnal Sosial Politik Dialektika Vol. 2 No. 2-2001, hlm. 20

${ }^{7}$ Setidaknya terdapat empat model penulisan istilah ini, yaitu presidentil, presidensil, presidensiil, dan presidensial dalam hukum tata negara.Dalam tesis ini digunakan istilah "presidensial" untuk menerjemahkan istilah "presidential". Lihat Anton M. Moeliono, Kamus Besar Bahasa Indonesia, Jakarta: Departemen Pendidikan dan Kebudayaan RI, 1988, hlm. 700.

${ }^{8}$ Bintan R. Saragih, Majelis Permusyawaratan Rakyat,Jakarta : Gaya Media Pratama, 1992, hlm.7

${ }^{9}$ Titik Triwulan Tutik, Konstruksi Hukum Tata Negara Indonesia Pasca Amandemen UUD 1945, Jakarta, Kencana Prenada Media 2011, hlm. 80

10 Kusnardi dan Harmaily Ibrahim, Pengantar Hukum Tata Negara Indonesia, Jakarta, PS HTN-FH UI dan Sinar Bakti, 1988 hlm. 177.
} 
1945 yang berbunyi sebagai berikut: Pasal 17 UUD 1945: (1) Presiden dibantu oleh menteri-menteri negara. (2) Menteri-menteri itu diangkat dan diberhentikan oleh Presiden. (3) Setiap menteri membidangi urusan tertentu dalam pemerintahan. (4) Pembentukan, pengubahan dan pembubaran kementerian negara diatur dalam undang-undang. Menurut C.S.T Kansil, Menteri-menteri itu diangkat dan diberhentikan oleh Presiden. Menterilah yang terutama menjalankan kekuasaan pemerintahan (pouvonir executive). 11

Berdasarkan ketentuan tersebut dapat dinyatakan bahwasanya para Menteri adalah Pembantu Presiden yang diangkat dan diberhentikan oleh Presiden sebagai pemegang kekuasaan pemerintahan sebagaimana rumusan Pasal 4 ayat (1) UUD 1945. Sehingga Menteri membantu Presiden menyelenggarakan urusan pemerintahan dalam bidang-bidang tertentu sesuai dengan tugas dan fungsinya guna mencapai tujuan negara sebagaimana diamanatkan dalam Pembukaan UUD 1945.

Selain itu mengenai Kementerian Negara diatur pula dalam Undangundang Nomor 39 Tahun 2008 tentang Kementerian Negara. Kedudukan Menteri dalam sistem presidensial merupakan pembantu Presiden yang berada di bawah dan bertanggung jawab sepenuhnya kepada Presiden sebagaimana Pasal 3 Undang-undang Nomor 39 Tahun 2008. Pasal 22 juga merumusakan: (1) Menteri diangkat oleh Presiden. Penjelasan ayat (1): Menteri dalam ketentuan ini adalah pejabat negara sesuai dengan ketentuan peraturan perundang-undangan.12

Berdasarkan pasal tersebut maka dapat dimaksudkan bahwa para menteri negara tunduk dan bertanggung jawab kepada presiden sebagai satu kesatuan institusi. Prinsip yang bersifat umum adalah administrasi pemerintahn pusat pada umumnya ditempatkan di bawah kewenangan menteri atau diorganisasikan sebagai kementerian atau departemen.

${ }^{11}$ C.S.T. Kansil dam Christina S.T. Kansil, Sistem Pemerintahan Indonesia, Edisi Revisi, Jakarta: Bumi Aksara, 2005, hlm.103.

${ }^{12}$ Para Menteri (dari PKS), Presidensial dan Koalisi (Parlementer) dalam.www.kompasiana.com diakses tanggal 24 Februari 2016 
Kewenangan untuk mengendalikan prilaku Kepala Daerah dan DPRD yang membentuk Peraturan Daerah yang bertentangan dengan kepentingan umum dan/atau Peraturan Perundang-Undangan yang lebih tinggi tidak lagi dilakukan oleh Presiden tetapi dilakukan oleh Menteri Dalam Negeri dan Gubernur sebagaimana Pasal 251 ayat (1) dan ayat (2) Undang-undang Nomor 24 Tahun 2014.

Berdasarkan Pasal 7 ayat (2) Undang-Undang No. 12 Tahun 2011 menentukan: Kekuatan hukum Peraturan Perundang-Undangan sesuai dengan hierarki sebagaimana dimaksud pada ayat (1). Ketentuan ini menjadi dasar adanya Peraturan Perundang-Undangan lain yang masuk dan menjadi bagian hirarkis peraturan perundang-undangan.

Pasal 8 ayat (1) Jenis Peraturan Perundang-Undangan selain sebagaimana dimaksud dalam Pasal 7 ayat (1) mencakup peraturan yang ditetapkan oleh Majelis Permusyawaratan Rakyat, Dewan Perwakilan Rakyat, Dewan Perwakilan Daerah, Mahkamah Agung, Mahkamah Konstitusi, Badan Pemeriksa Keuangan, Komisi Yudisial, Bank Indonesia, Menteri, badan,lembaga, atau komisi yang setingkat yang dibentuk dengan Undang-Undang atau Pemerintah atas perintah Undang-Undang, Dewan Perwakilan Rakyat Daerah Provinsi, Gubernur, Dewan Perwakilan Rakyat Daerah Kabupaten/Kota, Bupati/Walikota, Kepala Desa atau yang setingkat.

Perlu ditegaskan segala produk hukum sebagaimana tersebut di atas adalah "peraturan", yang secara prinsip berbeda dari "keputusan". Berdasarkan hal ini, Keputusan Mendagri bukan sebagai salah satu Peraturan Perundang-Undangan sebagaimana dimaksud Pasal 8 ayat (1) Undang-Undang No. 12 Tahun 2011, sehingga penilaian mengenai kedudukan dan kekuatan hukumnya bukan dilihat dari susunan hirarki peraturan perundang-undangan.

Maka dari itu apabila dibandingkan dengan misalnya Peraturan Dewan Perwakilan Rakyat Daerah Propinsi atau Peraturan Guburnur, suatu Peraturan Menteri Dalam Negeri mempunyai kedudukan lebih tinggi karena Peraturan Menteri disebutkan lebih dahulu. Analog dengan hal ini 
adalah kedudukan Keputusan Menteri, termasuk Keputusan Mendagri. Kedudukan Keputusan Menteri lebih tinggi dari Keputusan Dewan Perwakilan Rakyat Daerah Provinsi atau Keputusan Gubernur.

Pengujian terhadap Perda ini terdapat dualisme kewenangan pengujian terhadap Perda, yang pertama Mahkamah Agung yang dikenal sebagai judicial review dan yang kedua adalah Pemerintah Pusat yang dalam hal ini Menteri Dalam Negeri yang dikenal sebagai executive review. Pada dua model pengujian ini terdapat perbedaan yaitu pada model pengujian judicial review pengadilan bersifat pasif yaitu apabila ada yang mengajukan pengujian terhadap Perda saja baru mekanisme judicial review akan berjalan sedangkan pada model executive review bersifat aktif artinya Pemerintah Pusat dapat mendesak untuk Pemerintah untuk menyerahkan Perdanya untuk diuji, apabila tidak sesuai maka dibatalkan. Pembatalan Perda yang dilakukan oleh Pemerintah bukan merupakan pembatalan dalam ranah peradilan. Pembatalan Perda ini merupakan pengawasan represif dalam ranah hukum administrasi.

Kedudukan hukum Menteri Dalam Negeri dapat mengeluarkan keputusan Menteri Dalam Negeri tentang pembatalan Peraturan daerah yang didasarkan atas perintah dari suatu Undang-Undang atau atribusi dalam bentuk executive review. Menteri Dalam Negeri dalam keputusan tidak menyalahi selama tidak bertentangan dengan asas-asas dan norma pembentukan peraturan perundangundangan.

\section{Kewenangan yang Dijalankan oleh Menteri Dalam Negeri dalam Proses Pembatalan Peraturan Daerah}

Pembentukan Peraturan Daerah merupakan sebuah mekanisme untuk mencapai demokratisasi penyelenggaraan pemerintahan melalui otonomi daerah yang sesuai dengan tujuan hukum untuk mengayomi masyarakat daerah baik secara aktif maupun secara pasif. Secara aktif dimaksudkan sebagai upaya untuk menciptakan suatu kondisi kemasyarakatan daerah yang berlangsung secara wajar. Sedangkan yang dimaksud secara pasif adalah mengupayakan pencegahan atas 
upaya yang sewenang-wenang dan penyalahgunaan hak secara tidak adil. Begitu juga ketika suatu Peraturan Daerah akan dibatalkan, harus sesuai dengan alasanalasan yang bertujuan untuk mengayomi dan melindungi rakyat.

Usaha mewujudkan pengayoman ini termasuk di dalamnya diantaranya adalah mewujudkan keadilan, kepastian serta kemanfaatan hukum sebagaimana gagasan hukum Gustav Radbruch yang relevan dengan tiga aspek keberlakuan hukum sebagai berikut:

a. Keadilan Hukum : Kekuatan berlaku Filosofis

Secara filosofis, keadilan merupakan salah satu tujuan hukum yang paling banyak dibicarakan. Tujuan hukum bukan hanya keadilan, tetapi juga kepastian hukum dan kemanfaatan hukum. Idealnya, hukum memang harus mengakomodasikan ketiganya.

Menteri Dalam negeri dalam melakukan pembatalan memiliki wewenang dalam pembentukan keputusan pemerintahan yakni keputusan Menteri dalam negeri untuk pembatalan paraturan daerah harus memiliki pertanggungjawaban hukum dan berdasarkan keadilan masyarakat sebagaimana dalam UUD 1945. Hal ini sesuai dengan teori keadilan Gustav Radbruch.

b. Kepastian Hukum : Kekuatan berlaku Yuridis

Kepastian hukum merupakan pertanyaan yang hanya bisa dijawab secara normatif, bukan sosiologis. Kepastian hukum secara normatif adalah ketika suatu peraturan dibuat dan diundangkan secara pasti karena mengatur secara jelas dan logis. Jelas dalam artian tidak menimbulkan keragu-raguan (multi-tafsir) dan logis dalam artian ia menjadi suatu sistem norma dengan norma lain sehingga tidak berbenturan atau menimbulkan konflik norma. Konflik norma yang ditimbulkan dari ketidakpastian aturan dapat berbentuk kontestasi norma, reduksi norma atau distorsi norma.

Ketika sebuah peraturan ataupun Undang-Undang tidak mencerminkan keadilan sesuai dengan cita hukum tertinggi (recht side), kepastian hukum sesuai dengan hierarki Peraturan Perundang-Undangan Indonesia serta kemanfaatan bagi 
seluruh rakyat Indonesia maka berdasarkan teori Gustav Radbruch menurut penulis peraturan tersebut dapat dikoreksi ataupun dibatalkan.

Undang-Undang Nomor 12 Tahun 2011 tentang Pembentukan Peraturan Perundang-Undangan memuat produk hukum daerah utamanya peraturan daerah dalam jenis dan hierarki peraturan perundang-undangan, yaitu dalam Pasal 7. Sebagaimana sistem pembentukan Peraturan Perundang-Undangan pada Pasal 7 dianut adalah judicial review. Namun juga menganut excecutive review sebagimana Pasal 8 dan Pasal 97 Undang-Undang Nomor 12 Tahun 2011.

Keharusan adanya kesesuaian bentuk atau jenis Peraturan PerundangUndangan dengan materi yang diatur, terutama kalau diperintahkan oleh Peraturan Perundang-Undangan yang lebih tinggi atau sederajat. Bahwa Menteri Dalam Negeri dalam membatalkan peraturan daerah sesuai dengan kewenangan yang dimilikinya sesuai dengan Pasal 251 ayat (1) dan ayat (2) undang-undang nomor 23 tahun 2014.

Berdasar pada asas legalitas dan maksud dari isi Pasal 1 ayat (8) UndangUndang Republik Indonesia No. 51 Tahun 2009 tentang perubahan kedua atas Undang-Undang Nomor 5 Tahun 1986 tentang peradilan Tata Usaha Negara, memberikan suatu dasar dari keabsahan suatu Peraturan Perundang-Undangan terkait dengan wewenang pembuat Peraturan Perundang-Undangan tersebut, begitu pula halnya dengan peraturan daerah yang telah dibatalkan melalui keputusan Menteri dalam negeri, bahwa dasar wewenang yang dimiliki Menteri Dalam Negeri adalah telah tepat, sebagaimana telah diatur dalam Undang-Undang No. 23 Tahun 2014 tentang Pemerintahan Daerah mengenai mekanisme pembatalan peraturan daerah. Dengan demikian maka keputusan menteri dalam negeri dalam pembatalan peraturan daerah sesuai dengan aspek kepastian hukum menurut Gustav Radbruch.

c. Kemanfaatan Hukum : Kekuatan berlaku Sosial

Aliran utilitas menganggap bahwa pada prinsipnya tujuan hukum itu hanyalah untuk menciptakan kemanfaatan atau kebahagiaan masyarakat. Aliran utilitas memasukkan ajaran moral praktis yang menurut penganutnya bertujuan 
untuk memberikan kemanfaatan atau kebahagiaan yang sebesar-besarnya bagi sebanyak mungkin warga masyarakat.

Peraturan daerah lahir atas dasar prakarsa dan aspirasi masyarakat menuju terwujudnya supremasi sistem hukum. Sistem hukum yang hendak diwujudkan adalah sistem hukum di bawah sistem konstitusi yang berfungsi sebagai acuan dasar yang efektif dalam proses penyelenggaraan negara dan kehidupan nasional sehari-hari. Dalam upaya mewujudkan sistem hukum yang efektif itu, penataan kembali, kultur dan kesadaran hukum masyarakat yang terus meningkat, seiring dengan pembaruan materi hukum yang terstruktur secara harmonis, dan terus menerus diperbarui sesuai dengan tuntutan perkembangan kebutuhan. Pembatalan peraturan daerah dapat dilaksanakan oleh Menteri dalam negeri asalkan sesuai dengan aspek sosiologis dengan mempertimbangkan aspirasi dan prakarsa masyarakat.

Hal ini sesuai dengan pendapat Mochtar Kusumaatmadja, menyatakan bahwa tujuan utama adanya hukum adalah jaminan ketertiban, keadilan, dan kepastian. Dengan demikian, hukum adalah sebuah sistem yang mempunyai ciri dan karakteristik yang menjadi penggerak dan pengatur kehidupan masyarakat. Terkait dengan ciri dan karakteristik hukum dan masyarakat tersebut, Roscoe Pound, mengenalkan lebih lanjut apa yang disebut sebagai law as a tool of social engineering.

\section{Simpulan}

1. Kedudukan hukum Menteri Dalam Negeri membatalkan Peraturan Daerah melalui Keputusan Menteri Dalam Negeri menurut Undang-Undang nomor 23 tahun 2014 jo Undang-Undang Nomor 9 tahun 2015 telah sesuai aturan perundang-undangan dan secara mutatis mutandis sama dengan sistem hirarki peraturan perundang-undangan. Keputusan Mendagri yang membatalkan Perda tidak dilihat dari bagian sistem Peraturan Perundang-Undangan (dalam arti sempit yaitu dalam arti regeling). Melainkan sebagai analog dalam "susunan hirarkis keputusan". Apabila suatu produk keputusan dalam "hirarkis 
keputusan" adalah lebih tinggi, maka "keputusan" tersebut mempunyai kedudukan yang lebih tinggi juga dalam susunan hirarkis "peraturan". Keputusan Mendagri lebih tinggi dari Peraturan Daerah karenanya, dilihat dari sistem hirarkisnya.

2. Kewenangan Menteri Dalam Negeri dalam pembatalan Peraturan Daerah adalah wewenang atribusi. Kewenangan tersebut memiliki kekuatan mengikat karena diperintahkan oleh Peraturan Perundang-Undangan yang lebih tinggi yaitu Undang-Undang. Menteri Dalam Negeri melakukan Pembatalan Peraturan Daerah sesuai kewenangan yang dijalankan berdasarkan pada Konstitusi, hal mana keputusan tersebut mencerminkan kehidupan politik di dalam masyarakat sebagai suatu kenyataan (sosiologis dan politis), merupakan satu kesatuan kaidah yang hidup dalam masyarakat, dan mendasarkan pada hukum tertinggi yaitu UUD sebagai indikator untuk menilai perda yang akan dibatalkan. 


\section{DAFTAR PUSTAKA}

A. Mukthie Fadjar, 2005, Tipe Negara Hukum, Malang: Bayumedia Publishing.

Anton M. Moeliono, 1988, Kamus Besar Bahasa Indonesia, Jakarta: Departemen Pendidikan dan Kebudayaan RI.

Bintan R. Saragih, 1992 Majelis Permusyawaratan Rakyat,Jakarta : Gaya Media Pratama.

C.S.T. Kansil dam Christina S.T. Kansil, 2005 Sistem Pemerintahan Indonesia, Edisi Revisi, Jakarta: Bumi Aksara.

Miriam Budiardjo, 2005, Dasar-Dasar Ilmu Politik, Jakarta: Gramedia Pustaka Utama.

Ronny Hanitijo Soemitro, 1990, Metodologi Penelitian Hukum dan Yurimetri, Jakarta: GhaliaIndonesia.

Rukmana Amanwinata, Sistem Pemerintahan Indonesia, Jurnal Sosial Politik Dialektika Vol. 2 No. 2-2001

Satjipto Raharjo, 2000, Ilmu Hukum, Bandung: Citra Aditya Bakti.

Titik Triwulan Tutik, 1998, Konstruksi Hukum Tata Negara Indonesia Pasca Amandemen UUD 1945, Jakarta, Kencana Prenada Media 2011 Kusnardi dan Harmaily Ibrahim, Pengantar Hukum Tata Negara Indonesia, Jakarta, PS HTN-FH UI dan Sinar Bakti.

, "Para Menteri (dari PKS), Presidensial dan Koalisi (Parlementer)" dalam.www.kompasiana.com, diakses pada 2 Januari 2016.

, "Sejak November 2014 hingga Mei 2015 Mendagri Batalkan 139 Perda", http://nasional.kompas.com/, diakses pada 3 Januari 2016. 